\title{
STUDI KELENGKAPAN PENJELASAN INFORMASI CARA PENGGUNAAN CONTROLLERMETERED-DOSE INHALER (MDI) YANG MENGANDUNG KORTIKOSTEROID SEBAGAI TERAPI ASMA DI APOTEK KABUPATEN TUBAN
}

\author{
Submitted : 20 Maret 2017 \\ Edited : 15Mei 2017 \\ Accepted : 23 Mei 2017 \\ Amelia Lorensia ${ }^{1}$, Jessica Nathania ${ }^{2}$ \\ ${ }^{1}$ Departement of Clinical-Community Pharmacy, Faculty of Pharmacy, Surabaya of University \\ (Universitas Surabaya (UBAYA)) \\ ${ }^{2}$ Postgraduate Student of Bachelor of Pharmacy Science, Faculty of Pharmacy, Surabaya of \\ University (Universitas Surabaya (UBAYA)) \\ Email : amelia.lorensia@gmail.com
}

\begin{abstract}
This experiment centred in metered dose inhaler (MDI) device which used routinely by asthma patient as controller therapy. MDI used ask patient's skill more when using their medication. MDI technique informnation provided by pharmachist are important to achive optimal medication in asthma therapy. By a non experimental study, mysterious patient collect MDI technique gived by pharmacist in Tuban pharmacy using observacional and cross sectional method. Information about MDI technique comprehensive collected by two ratter as mysterious patient which assessed with checklist that got measseured by kappa to know ratter aggrement percentage. The result showed from a total sampling under 41 pharmachist which represent each 41 pharmacy in Tuban, by purposive sampling Pharmacists as pharmaceutical personnel responsible for information services at pharmacies, including information on how to use MDI. Most of the apothecary's ability level in providing information is still lacking, then continued with adequate technique, and optimal technique in providing complete information of MDI use for asthma patient. Pharmacists know how to use MDI and no pharmacist is unexpected or not familiar with MDI as an asthma therapy. Pharmacists in Tuban district have a tendency to inform only four stages of the nine stages of MDI use from Osman et al (2012), ie at the 1st, 3rd, 5th, and 6th stages of MDI use.
\end{abstract}

Keywords : controller, metered dose inhaler (MDI), drug information, pharmacist

\section{PENDAHULUAN}

Asma salah satu penyakit kronis di dunia, diperkirakan telah mencapai 300 juta jiwa penduduk dengan peningkatan prevalensi sebanyak 100 juta jiwa pada tahun $2025^{(1)}$. Di Indonesia, asma menduduki peringkat sepuluh sebagai penyakit dan penyebab kematian (Survei Kesehatan Rumah Tangga atau SKRT) ${ }^{(2)}$.
Rata-rata prevalensi asma untuk seluruh wilayah Indonesia sebesar 3,32\% dan Jawa timur sebesar $2,62 \%{ }^{(3)}$. Tujuan utama penatalaksanaan asma adalah meningkatkan dan mempertahankan kualitas hidup, agar pasien dapat hidup normal tanpa hambatan dalam melakukan aktivitas sehari-hari ${ }^{(2)}$. Penatalaksanaan asma secara rutin menggunakan terapi controller digunakan 
secara teratur setiap hari. Golongan yang merupakan lini pertama pilihan agen controller adalah inhaled glucocorticosteroids (ICS) yang terkadang sering dikombinasikan dengan beta-2 agonis $^{(4)}$.

Kemajuan pada pengobatan asma adalah dengan merubah rute pemberian obat secara oral menjadi inhalasi dengan bentuk sediaan aerosol, yaitu MDI (metered-dose

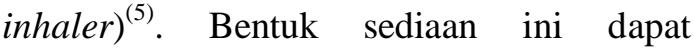
menghantarkan obat secara langsung dalam dosis yang lebih kecil dan efektif, mengurangi efek samping dan dengan onset bronkodilator lebih cepat $^{(1)}$. Namun penggunaan inhaler membutuhkan keterampilan lebih dalam hal koordinasi pada saat menarik dan menahan nafas, serta mengeluarkan dosis obat dari inhaler secara tepat ${ }^{(6)}$. Kesulitan penggunaan MDI ditemukan pada lansia dan anak-anak, yang dapat berisiko menyebabkancandidiasis orofaringeal $^{(4,6)}$. Selain itu, kesulitan penggunaan alat, membawa dampak kesalahan penggunaan alat inhalasi, menyebabkan tidak terkontrolnya asma, meningkatnya eksaserbasi asma, tidak optimalnya dosis yang diterima pasien, dan peningkatan dosis obat yang seharusnya belum diperlukan ${ }^{(7)}$.

Terwujudnya pengobatan yang optimal pada terapi asma, memerlukan peran apoteker dalam memantau tingkat level asma pasien, serta memberikan pengetahuannya untuk menggunakan inhaler ICS secara benar untuk pengobatan jangka panjang asma ${ }^{(8)}$. Di samping itu, MENKES tahun 2004 dalam Standar Pelayanan Kefarmasian tahun 2004 mengatur kewajiban farmasis untuk memberikan konseling dan monitoring penggunaan obat terlebih pada pasien dengan penyakit tertentu salah satunya asma ${ }^{(9)}$. Maka penting mengetahui kemampuan apoteker di apotek dalam menggunakan alat inhalasi asma karena teknik penggunaan inhaler adalah faktor penentu, apakah pasien memperoleh keuntungan atau kerugian pada terapi jangka panjang asma. Instruksi lisan secara jelas dengan teknik yang benar, disertai demonstrasi alat, sangat efektif dan telah menunjukkan peningkatan kemajuan pada data klinik pasien. Keberhasilan pengobatan asma tidak bergantung dari tipe alat inhalasi yang diresepkan, pasien tidak akan menggunakan alat secara tepat dan benar apabila tidak mendapatkan instruksi yang jelas serta demonstrasi penggunaan alat tersebut $^{(7)}$.

Studi yang dilakukan di kalangan tenaga kesehatan kefarmasian untuk memantau penggunaan MDI dengan menggunakan pasien misterius ${ }^{(10)}$ dan menggunakan daftar checklist yang berisi sembilan tahapan penggunaan alat inhalasi, ditemukan bahwa rendahnya kontrol pada asma dilatarbelakangi oleh kurangnya waktu yang disediakan oleh petugas kesehatan untuk menjawab pertanyaan yang diajukan oleh pasien dan kurangnya pengetahuan yang dimiliki apoteker akan penggunaan alat inhalasi $^{(5,10,11)}$.

Pada penelitian ini juga menggunakan pasien misterius, sesuai metode yang digunakan pada penelitian Osman dkk (2012) ${ }^{(10)}$. Pasien misterius adalah tenaga terlatih yang bertugas melakukan evaluasi mengenai kinerja tenaga professional, pasien misterius membekali diri dengan naskah dan daftar pertanyaan untuk tenaga professional. Di sini pasien misterius memiliki keuntungan dapat melihat gambaran kejadian yang sebenarnya secara mendalam ${ }^{(12)}$. Dari latar belakang tersebut maka penelitian ini bertujuan mengetahui kemampuan apoteker di daerah kabupaten Tuban dalam memberikan penjelasan mengenai penggunaan MDI yang mengandung kortikosteroid. 


\section{METODE PENELITIAN}

\section{Desain Penelitian}

Merupakan penelitian observasional dengan desain cross sectional. Menganalisis masalah yang sering terjadi pada pemberian informasi pada penggunaan controller MDI pada praktek di apotek kabupaten Tuban. Sebagai bahan dalam penelitian ini adalah informasi yang diberikan oleh apoteker mengenai pemakaian controller MDI dan daftar checklists. Lokasi penelitian adalah apotek yang memiliki ijin praktek di Kabupaten Tuban. Pengambilan data untuk penelitian ini dilakukan pada Bulan Januari 2014 sampai bulan Desember 2015.

\section{Variabel Penelitian}

Variabel penelitian yang diteliti adalah penjelasan teknik penggunaan controller MDI yang mengandung kortikosteroid oleh apoteker. Informasi mengenai penggunaan controller MDI oleh apoteker adalah kelengkapan informasi tahapan penggunaan MDI. Informasi ini mencakup sembilan tahap langkah penggunaan dengan tiga tahap diantaranya adalah tahap critical step (Tabel 1). Tahap critical step berfungsi sebagai penentu kategori yang akan digunakan untuk mengolah data informasi oleh apoteker menjadi nilai tingkatan kemampuan apoteker dalam memberikan informasi penjelasan penggunaan MDI.

\section{Populasi dan Sampel}

Populasi adalah seluruh apoteker di apotek di kabupaten Tuban, Jawa Timur yang bersedia memberikan informasi penggunaan controller MDI. Sampel adalah semua apoteker yang memiliki status sebagai apoteker penanggung jawab apotek maupun apoteker pendamping yang melaksanakan pekerjaan kefarmasian di apotek kabupaten Tuban, Jawa Timur dan bersedia memberikan informasi dan menjawab wawancara terkait penggunaan controller MDI. Setiap apotek diwakili oleh 1 pemberi informasi yaitu apoteker atau apoteker yang diwakilkan oleh tenaga kefarmasian.

Besar sampel dalam penelitian ini adalah total sampling. Pengambilan total sampel ini dikarenakan populasi terjangkau berukuran cukup kecil, yaitu sebesar 41 apoteker. Jumlah 41 apoteker sebagai sampel didapatkan dari jumlah 41 apotek dari Dinas Kesehatan kabupaten Tuban tahun 2014.

Tabel 1. Sembilan tahapan penggunaan controller MDI

\section{No. Tahapan penggunaan controller MDI \\ 1.* Buka tutup inhaler \\ 2.* Kocok inhaler beberapa kali. \\ 3. Berdiri dan pada posisi kepala tegak, pastikan memegang inhaler dengan bagian mouthpiece (mulut inhaler) berada pada posisi bagian bawah.}

4. Hembuskan nafas secara perlahan sampai tidak ada sisa udara yang dapat dihembuskan.

5. Posisikan mulut inhaler mengarah ke rongga mulut yang terbuka. Dan aliran udara tidak terganggu, dengan jalan lidah tidak menutupi bagian mulut inhaler.

6.* Tekan canister (ujung bagian atas inhaler) untuk mengeluarkan dosis, dan pada waktu bersamaan mulailah menarik nafas dalam secara perlahan (koordinasi)

7. Lanjutkan untuk bernapas perlahanlahan selama 4-5 detik

8. Tahan napas selama 10 detik

9. Hembuskan nafas secara perlahan lahan

Total score 
Keterangan : * = "critical step" ${ }^{(10)}$

\section{Metode Pengambilan Data}

Kronologi pengambilan data dalam penelitian ini adalah sebagai berikut:

1. Melakukan survei data mengenai jumlah apotek yang masih aktif di kabupaten Tuban.

2. Mengirimkan lembar inform consent kepada tiap-tiap apotek di kabupaten Tuban.

3. Setelah didapatkan jumlah apotek yang bersedia, pasien misterius melakukan pengambilan sampel. Sampel yang diambil adalah data informasi yang diberikan oleh apoteker dalam memberikan demonstrasi penggunaan controller MDI yang mengandung kortikosteroid yang menjadi alat yang diujikan.

Urutan cara memperoleh informasi yang diinginkan sesuai model metodologi penelitian pada penelitian ini adalah sebagai berikut :

1. Dua orang pasien misterius datang menemui subjek penelitian. Seorang pasien misterius memberikan MDI yang dibawanya kepada Apoteker dan meminta penjelasan informasi cara penggunaannya secara demonstrasi alat. Apoteker selaku subjek penelitian tidak mengetahui apabila mereka sedang dimintai informasi untuk sebuah data penelitian. Apoteker dikondisikan seperti memberikan informasi sehari-hari terhadap pasien yang datang berkunjung ke apotek untuk membeli obat dan bertanya mengenai obat mereka. Seperti: "Dapatkah anda menolong saya dalam menjelaskan cara penggunaan alat inhalasi ini ?"

2. Kedua pasien misterius melakukan observasi terhadap informasi yang diberikan oleh apoteker. Pasien misterius juga merekam informasi yang diberikan oleh apoteker melalui media rekam suara.
Hal ini dilakukan untuk menyimpan data informasi yang nantinya digunakan sebagai media pembantu untuk mengisi daftar checklist untuk mengukur kemampuan apoteker dalam memberikan informasi mengenai pengguaan controller MDI.

3. Pasien misterius menggali secara lisan informasi tambahan mengenai alasan dan penyebab terkait kemampuan apoteker yang beragam terhadap tata cara penggunaan controller MDI.

4. Kedua pasien misterius mengisi tabel tahapan penggunaan controller MDI

5. Data yang di ambil oleh pasien misterius akan dimasukkan dalam kategorikategori yang telah dibuat untuk memberikan profil mengenai kemampuan apoteker ke dalam daftar checklist yang sebelumnya telah disiapkan oleh peneliti yang dalam penelitian ini juga bertindak sebagai salah satu pasien misterius. Data informasi tambahan akan dimasukkan dalam kolom wawancara secara narasi, guna melengkapi pertanyaan-pertanyaan yang akan timbul dari fenomena hasil penelitian yang didapatkan.

\section{Analisis Data}

Data informasi yang diperoleh pasien misterius dari subjek yang merupakan sampel di lingkungan pengambilan data menghasilkan data nominal dan ordinal dan ditampilkan dalam bentuk statistik deskriptif. Data nominal ditujukan pada nilai yang merupakan total jumlah apoteker yang memberikan penjelasan secara benar untuk setiap step penggunaan controller MDI. Jumlah frekuensi data nominal yang dihasilkan adalah jumlah step penggunaan controller MDI, yaitu 9. Frekuensi ini digandakan sesuai jumlah pasien misterius dalam penelitian. Penelitian ini menggunakan 2 pasien misterius untuk mengambil data nominal. Peneliti merangkap sebagai pasien misterius 1 bersama interrater sebagai pasien misterius 2 memberikan skor nominal yang akan diuji 
kesamaan persepsinya menggunakan uji interrater reliability, yaitu koefisien kappa. Nilai maksimal data nominal yang dihasilkan adalah jumlah apoteker dalam penelitian, nilai minimal yang dihasilkan adalah 0 yaitu tidak ada apoteker yang dapat menjelaskan penggunaan controller MDI. Prinsip dari uji interrater reliability adalah sebagai berikut :

1. Bila nilai koefisien kappa antara 0,811,00 dengan nilai $\mathrm{p}$ atau $\mathrm{p}$ alpha $(0,05)$, maka persepsi antara interrater sama.

2. Bila nilai koefisien kappa $<0,81$ dengan nilai $p$ atau $p$ alpha $(0,05)$, maka persepsi antara interrater terjadi perbedaan.

Data ordinal dalam penelitian ini ditujukan pada nilai skor yang diwujudkan dalam bentuk kalimat. Kalimat ini merupakan keterangan yang menuju kepada peringkat "teknik optimal", "teknik adekuat", "teknik kurang", "tidak tahu", dan "tidak familiar", dengan peringkat "teknik optimal" lebih tinggi daripada "teknik adekuat", "teknik adekuat" lebih tinggi daripada "teknik kurang", "teknik kurang" lebih tinggi daripada "tidak tahu", dan "tidak tahu" lebih tinggi daripada "tidak familiar". Penentuan peringkat ini didasarkan pada tahapan critical step penggunaan MDI yang menunjuk pada step nomor 1, step nomor 2, dan step nomor 6 (Tabel 2).

Tabel 2. Kategori Kemampuan Apoteker ${ }^{(10)}$

\begin{tabular}{|c|c|}
\hline Kategori & Penjelasan terkait kategori \\
\hline Te & $\begin{array}{l}\text { Dapat menyebutkan semua } \\
\text { langkah secara tepat }\end{array}$ \\
\hline $\begin{array}{l}\text { Teknik } \\
\text { adekuat }\end{array}$ & $\begin{array}{l}\text { Dapat menyebutkan semua } \\
\text { "critical step”, tetapi tidak } \\
\text { semua tahapan lengkap }\end{array}$ \\
\hline $\begin{array}{l}\text { Teknik } \\
\text { kurang }\end{array}$ & $\begin{array}{l}\text { Tidak dapat menyebutkan } \\
\text { semua secara lengkap dari } \\
\text { tahapan "critical step" }\end{array}$ \\
\hline Tidak tahu & $\begin{array}{l}\text { Tidak dapat } \\
\text { mendemonstrasikan inhaler }\end{array}$ \\
\hline $\begin{array}{l}\text { Tidak } \\
\text { familiar }\end{array}$ & $\begin{array}{l}\text { Tidak pernah melihat alat } \\
\text { tersebut }\end{array}$ \\
\hline
\end{tabular}

\section{HASIL PENELITIAN}

\section{Data Demografi Sampel Penelitian}

Besar sampel penelitian ini sebanyak 41 apoteker yang masing-masing mewakili 41 apotek, sehingga data yang dikumpulkan sebanyak 41 lembar checklist yang dilakukan dengan apoteker dari masingmasing apotek. Tidak semua apoteker bersedia ditemui oleh pasien misterius yang berperan sebagai pasien asma untuk menanyakan cara penggunaan MDI. Apoteker yang tidak bersedia ditemui oleh pasien misterius dapat dikarenakan tidak hadir (sudah ditanyakan kesediaan waktu/jadwal untuk bertemu), tidak bersedia menemui (hadir di apotek namun tidak bersedia bertemu),atau apoteker jarang datang ke apotek. Dari 41 apotek, 25 apoteker (yang mewakili masing-masing apotek) bersedia untuk menjelaskan pada pasien misterius mengenai cara penggunaan MDI, 16 apotek dilakukan oleh nonapoteker.

\section{Kelengkapan Penjelasan Setiap Tahapan Cara Penggunaan Sediaan MDI}

Data yang dikumpulkan oleh pasien misterius dari sumber informasi apoteker adalah kelengkapan tahap penggunaan MDI dari sembilan tahap dengan tiga diantaranya adalah tahap critical step yang menjadi penentu kategori kemampuan apoteker, untuk itu data nominal yang dihasilkan dari checklist diolah dalam statistik deskritif untuk dicari frekuensi jumlah apoteker yang memberikan informasi benar dalam setiap tahap step, dan dihitung persentase dari total apoteker dan non-apoteker yang terlibat (Tabel 3).

\section{TingkatCritical Step pada Penjelasan Penggunaan Sediaan MDI di Kabupaten Tuban}

Kelengkapan data penjelasan cara pakai MDI berdasarkan critical step yang diberikan oleh masing-masing apoteker 
(sampel penelitian), persentase menunjukkan bahwa jumlah apoteker yang menjawab penjelasan penggunaan MDI berdasarkan critical step, terhadap total apoteker yang terlibat dalam penelitian, menunjukkan urutan tertinggi hingga terendah dimulai dari teknik kurang sebesar $53,66 \%$, kemudian diikuti dengan teknik adekuat $4,88 \%$, teknik optimal 2,44\%. Sedangkan kelengkapan data penjelasan cara pakai MDI berdasarkan critical step yang diberikan oleh non-apoteker menunjukkan bahwa urutan tertinggi hingga terendah dimulai dari teknik kurang yaitu $34,15 \%$, kemudian diikuti dengan teknik adekuat dan tidak familiar yaitu masing-masing 2,44\%, tidak ada non apoteker yang termasuk dalam kategori teknik optimal dan tidak tahu (Tabel 4).

\section{Ketersediaan dan Pelayanan Controller MDI yang Mengandung Kortikosteroid di Apotek}

Observasi yang dilakukan oleh pasien misterius di kabupaten Tuban, dengan total 41 apotek, didapatkan 40 apotek menjual inhaler, termasuk MDI, 1 apotek tidak menjual inhaler, 13 apotek pernah menjual MDI dengan kondisi 5 diantara 13 apotek tersebut pada saat peneliti melakukan pengambilan data tidak menjual, 2 diantaranya beralih pada bentuk sediaan controller DPI (dry-powder inhaler) (Tabel $5)$.

Ketersediaan MDI di apotek terhadap kelengkapan setiap step yang dijelaskan apoteker dibedakan dari apotek yang memiliki ketersediaan MDI dan tidak. Apotek yang memiliki ketersediaan MDI memiliki jumlah frekuensi benar tertinggi pada step 1 dan 6 sebanyak masing-masing 7 apoteker, step 5 sebanyak 6 apoteker, step 3 sebanyak 5 apoteker, dan tidak ada informasi yang dijelaskan oleh apoteker untuk step 2, 4, 7, 8, dan 9. Apotek yang tidak memiliki ketersediaan MDI memiliki jumlah frekuensi benar tertinggi pada step 6 sebanyak 18 apoteker, step 5 sebanyak 17 apoteker, step 1 sebanyak 16 apoteker, step 8 sebanyak 5 apoteker, step 7 sebanyak 4 apoteker, step 2 sebanyak 3 apoteker dan step 9 sebanyak 1 apoteker (Tabel 6).

Frekuensi jumlah apoteker terhadap kategori teknik dengan ketersediaan MDI, terbagi dalam Apotek yang memiliki ketersediaan controller MDI yang mengandung kortikosteroid dan tidak mengandung kortikosteroid.Apotek dengan ketersediaan MDI hanya memiliki satu macam teknik kemampuan yaitu teknik kurang dengan jumlah 7 apoteker, kategori kemampuan pada apotek yang tidak memiliki ketersediaan MDI memiliki 3 macam kategori kemampuan yaitu teknik optimal sebanyak 1 apoteker, teknik adekuat sebanyak 2 apoteker, dan teknik kurang sebanyak 15 apoteker (Tabel 7).

\section{Penjelasan Tambahan terkait Penggunaan Controller MDI yang mengandung kortikosteroid di Apotek}

Tabel 8 menggambarkan jumlah apoteker yang memberikan konseling terkait penggunaan MDI yang mengandung kortikosteroid dimana hanya sebanyak 7 apoteker memberikan penjelasan terkait berkumur setelah menggunakan sediaan ICS dari total 25 apoteker yang terlibat dan dari 41 total sampel apoteker. 
Tabel 3. Apoteker dan Non-Apoteker yang menjawab Setiap Tahapan Penjelasan Penggunaan Controller MDI yang mengandung Kortikosteroid

\begin{tabular}{|c|c|c|c|c|c|c|}
\hline \multirow{3}{*}{$\begin{array}{c}\text { Tahapan } \\
\text { ke- }\end{array}$} & \multicolumn{4}{|c|}{$\begin{array}{l}\text { TENAGA KEFARMASIAN YANG } \\
\text { MEMBERIKAN INFORMASI }\end{array}$} & \multirow{2}{*}{\multicolumn{2}{|c|}{$\begin{array}{c}\text { TOTAL } \\
(n=41)\end{array}$}} \\
\hline & \multicolumn{2}{|c|}{$\begin{array}{c}\text { APOTEKER } \\
(\mathbf{n}=25)\end{array}$} & \multicolumn{2}{|c|}{$\begin{array}{l}\text { NON-APOTEKER } \\
(n=16)\end{array}$} & & \\
\hline & Jumlah & $(\%)$ & Jumlah & $(\%)$ & Jumlah & $(\%)$ \\
\hline 1 & 23 & 56,10 & 14 & 34,15 & 37 & 90,24 \\
\hline 2 & 3 & 7.32 & 1 & 2,44 & 4 & 9,76 \\
\hline 3 & 19 & 46,34 & 10 & 24.39 & 29 & 70,73 \\
\hline 4 & 2 & 4.88 & 1 & 2.44 & 3 & 7,32 \\
\hline 5 & 23 & 56,10 & 13 & 31.71 & 36 & 87,80 \\
\hline 6 & 25 & 60.98 & 15 & 36,59 & 40 & 97,56 \\
\hline 7 & 4 & 9.76 & 1 & 2,44 & 5 & 12,20 \\
\hline 8 & 5 & 12,20 & 1 & 2,44 & 6 & 14,63 \\
\hline 9 & 1 & 2,44 & 0 & 0,00 & 1 & 2,44 \\
\hline
\end{tabular}

Keterangan: (\%): persentase dari total sampel

Tabel 4. Kelengkapan Penjelasan Penggunaan MDI Berdasarkan Critical Step

\begin{tabular}{|c|c|c|c|c|c|c|c|}
\hline \multirow{3}{*}{\multicolumn{2}{|c|}{$\begin{array}{c}\text { KELENGKAPAN } \\
\text { PENJELASAN MDI } \\
\text { BERDASARKAN } \\
\text { CRITICAL STEP }\end{array}$}} & \multicolumn{4}{|c|}{$\begin{array}{l}\text { TENAGA KEFARMASIAN YANG } \\
\text { MEMBERIKAN INFORMASI }\end{array}$} & \multicolumn{2}{|c|}{ TOTAL } \\
\hline & & \multicolumn{2}{|c|}{ APOTEKER } & \multicolumn{2}{|c|}{$\begin{array}{c}\text { NON- } \\
\text { APOTEKER }\end{array}$} & \multirow[t]{2}{*}{ Jumlah } & \multirow[t]{2}{*}{$(\%)$} \\
\hline & & Jumlah & $(\%)$ & Jumlah & $(\%)$ & & \\
\hline $\begin{array}{l}\text { Teknik } \\
\text { Optimal }\end{array}$ & $\begin{array}{l}\text { Dapat } \\
\text { menyebutkan } \\
\text { semua step secara } \\
\text { tepat }\end{array}$ & 1 & 2,44 & 0 & 0,00 & 1 & 2,44 \\
\hline $\begin{array}{l}\text { Teknik } \\
\text { Adekuat }\end{array}$ & $\begin{array}{l}\text { Dapat menjawab } \\
\text { semua "critical } \\
\text { step", tetapi tidak } \\
\text { semua step }\end{array}$ & 2 & 4,88 & 1 & 2,44 & 3 & 7,32 \\
\hline $\begin{array}{l}\text { Teknik } \\
\text { Kurang }\end{array}$ & $\begin{array}{l}\text { Tidak dapat } \\
\text { menjawab semua } \\
\text { "critical step" } \\
\text { secara lengkap }\end{array}$ & 22 & 53,66 & 14 & 34,15 & 36 & 87,80 \\
\hline $\begin{array}{l}\text { Tidak } \\
\text { Tahu }\end{array}$ & $\begin{array}{l}\text { Tidak dapat } \\
\text { mendemonstrasikan }\end{array}$ & 0 & 0,00 & 0 & 0,00 & 0 & 0,00 \\
\hline $\begin{array}{l}\text { Tidak } \\
\text { Familiar }\end{array}$ & $\begin{array}{l}\text { Tidak pernah } \\
\text { melihat alat } \\
\text { tersebut } \\
\text { sebelumnya }\end{array}$ & 0 & 0,00 & 1 & 2,44 & 1 & 2,44 \\
\hline & TOTAL & 25 & 61 & 16 & 39 & 41 & 100 \\
\hline
\end{tabular}

Keterangan: (\%): persentase dari total sampel 
Tabel 5. Distribusi Frekuensi Ketersediaan dan Pelayanan Sediaan Controller MDI yang Mengandung Kortikosteroid di Apotek

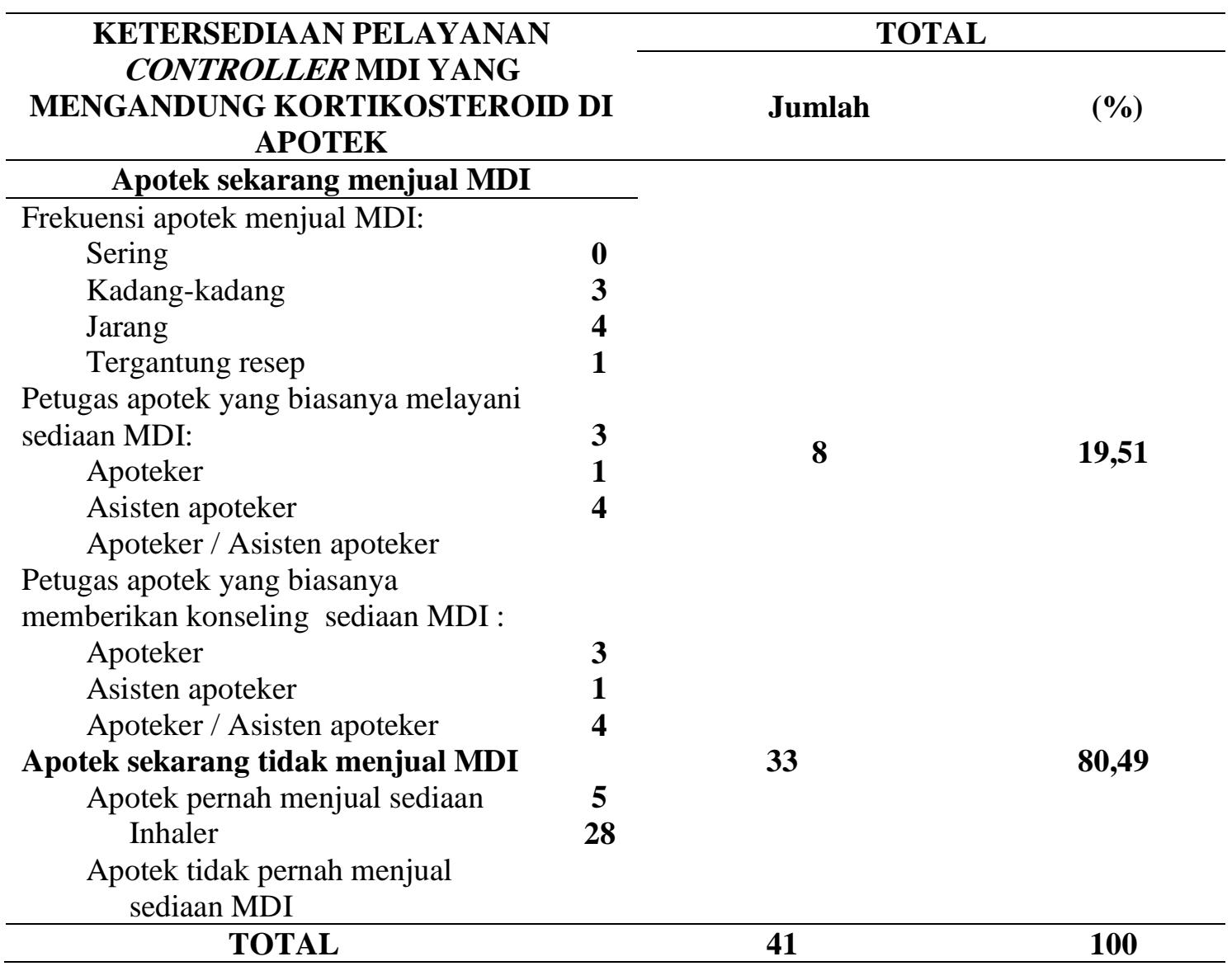

Tabel 6. Tabulasi Silang antara Kelengkapan Penjelasan Setiap Tahapan Cara Penggunaan Inhaler oleh Apoteker dengan Ketersediaan Controller MDI yang mengandung Kortikosteroid di Apotek

\begin{tabular}{|c|c|c|c|c|c|c|}
\hline \multirow{3}{*}{$\begin{array}{c}\text { Tahapan } \\
\text { ke- }\end{array}$} & \multicolumn{4}{|c|}{$\begin{array}{c}\text { KETERSEDIAAN CONTROLLER MDI } \\
\text { YANG MENGANDUNG } \\
\text { KORTIKOSTEROIDDI APOTEK }\end{array}$} & \multicolumn{2}{|c|}{ TOTAL APOTEKER } \\
\hline & \multicolumn{2}{|c|}{ TERSEDIA } & \multicolumn{2}{|c|}{ TIDAK TERSEDIA } & \multirow[b]{2}{*}{ Jumlah } & \multirow[b]{2}{*}{$(\%)$} \\
\hline & Jumlah & $(\%)$ & Jumlah & $(\%)$ & & \\
\hline $\mathbf{1}$ & 7 & 28,00 & 16 & 64,00 & 23 & 92,00 \\
\hline 2 & 0 & 0.00 & 3 & 12,00 & 3 & 12,00 \\
\hline 3 & 5 & 20,00 & 14 & 56,00 & 19 & 76,00 \\
\hline 4 & 0 & 0.00 & 2 & 8,00 & 2 & 8,00 \\
\hline 5 & 6 & 24,00 & 17 & 68,00 & 23 & 92,00 \\
\hline 6 & 7 & 28,00 & 18 & 72,00 & 25 & 100,00 \\
\hline 7 & 0 & 0.00 & 4 & 16,00 & 4 & 16,00 \\
\hline 8 & 0 & 0.00 & 5 & 20,00 & 5 & 20,00 \\
\hline 9 & 0 & 0.00 & 1 & 4,00 & 1 & $\mathbf{4 , 0 0}$ \\
\hline
\end{tabular}

Keterangan: (\%): persentase dari total sampel penelitian (apoteker) 
Tabel 7. Tabulasi Silang antara Kelengkapan Penjelasan Cara Penggunaan MDI Berdasarkan Cricital Step oleh Apoteker dengan Ketersediaan MDI di Apotek

\begin{tabular}{|c|c|c|c|c|c|c|}
\hline \multirow{3}{*}{$\begin{array}{c}\text { KELENGKAPAN } \\
\text { PENJELASAN } \\
\text { MDI } \\
\text { BERDASARKAN } \\
\text { CRITICAL STEP }\end{array}$} & \multicolumn{4}{|c|}{$\begin{array}{c}\text { KETERSEDIAAN CONTROLLER MDI } \\
\text { YANG MENGANDUNG } \\
\text { KORTIKOSTEROIDDI APOTEK }\end{array}$} & \multirow{2}{*}{\multicolumn{2}{|c|}{ TOTAL APOTEKER }} \\
\hline & \multicolumn{2}{|c|}{ TERSEDIA } & \multicolumn{2}{|c|}{ TIDAK TERSEDIA } & & \\
\hline & Jumlah & $(\%)$ & Jumlah & $(\%)$ & Jumlah & $(\%)$ \\
\hline Teknik Optimal & 0 & 0,00 & 1 & 4,00 & 1 & 4,00 \\
\hline Teknik Adekuat & 0 & 0,00 & 2 & 8,00 & 2 & 8,00 \\
\hline Teknik Kurang & 7 & 28,00 & 15 & 60,00 & 22 & 88,00 \\
\hline Tidak Tahu & 0 & 0,00 & 0 & 0,00 & 0 & 0,00 \\
\hline Tidak Familiar & 0 & 0,00 & 0 & 0,00 & 0 & 0,00 \\
\hline TOTAL & 7 & 28,00 & 18 & $\mathbf{7 2 , 0 0}$ & 25 & 100 \\
\hline
\end{tabular}

Keterangan: (\%): persentase dari total sampel penelitian (apoteker)

Tabel 8. Distribusi Frekuensi Penjelasan Sampel Penelitian (Apoteker) terkait Penggunaan controller MDI yang mengandung kortikosteroid (Inhaled Corticosteroid) di Apotek yang Terlibat dalam Penelitian

\begin{tabular}{|c|c|c|c|c|c|c|}
\hline \multirow{3}{*}{$\begin{array}{l}\text { INFORMASI } \\
\text { TAMBAHAN } \\
\text { DALAM } \\
\text { PENJELASAN }\end{array}$} & \multicolumn{4}{|c|}{$\begin{array}{l}\text { TENAGA KEFARMASIAN YANG } \\
\text { MEMBERIKAN INFORMASI }\end{array}$} & \multirow{2}{*}{\multicolumn{2}{|c|}{$\begin{array}{l}\text { TOTAL } \\
(n=41)\end{array}$}} \\
\hline & \multicolumn{2}{|c|}{$\begin{array}{l}\text { APOTEKER } \\
(n=25)\end{array}$} & \multicolumn{2}{|c|}{$\begin{array}{l}\text { NON-APOTEKER } \\
(\mathbf{n = 1 6 )})\end{array}$} & & \\
\hline & Jumlah & $(\%)$ & Jumlah & $(\%)$ & Jumlah & $(\%)$ \\
\hline $\begin{array}{l}\text { Penjelasan efek } \\
\text { samping yang } \\
\text { sering/dapat muncul } \\
\text { akibat penggunaan ICS }\end{array}$ & 0 & 0 & 0 & 0 & 0 & 0 \\
\hline $\begin{array}{l}\text { Penggunaan ICS } \\
\text { dengan memberikan } \\
\text { jarak antara mulut } \\
\text { dengan mouthpiece }\end{array}$ & 0 & 0 & 0 & 0 & 0 & 0 \\
\hline $\begin{array}{l}\text { Kumur dengan air } \\
\text { setelah menggunakan } \\
\text { ICS }\end{array}$ & 7 & 17,07 & 2 & 4,878 & 9 & 21,95 \\
\hline $\begin{array}{l}\text { Tidak memberikan } \\
\text { penjelasan }\end{array}$ & 18 & 43,90 & 14 & 34,15 & 32 & 78,05 \\
\hline TOTAL & 25 & 60,98 & 16 & 39,02 & 41 & 100 \\
\hline
\end{tabular}




\section{PEMBAHASAN}

Penelitian ini dilakukan di Kabupaten Tuban, daerah dengan kondisi sarana fasilitas tenaga kefarmasian khususnya dalam penelitian ini adalah apotek memiliki frekuensi jumlah yang kurang dan tidak tersebar merata di setiap area lingkungan kabupaten. Terdapat area yang tidak memiliki akses terhadap apotek, dan area minim apotek, untuk itu alangkah baiknya bila apotek yang ada mampu memberikan pelayanan yang optimal, sehingga usaha lebih yang dikeluarkan oleh pasien untuk memperoleh fasilitas kesehatan dapat sebanding dengan hasil yang didapatkan.

Pada penelitian ini, pasien misterius menyerahkan MDI beserta kemasan primer dan brosur dari produk obat tersebut, dimana sebenarnya apoteker dapat membaca brosur untuk sebagai informasi dalam menjelaskan MDI tersebut. Namun berdasarkan dari pengakuan beberapa sampel penelitian yang mengatakan kesulitan membaca brosur karena brosur menggunakan bahasa inggris. Cheklist yang digunakan dalam menilai kelengkapan penjelasan ada sembilan tahapan $^{(10)}$, sedangkan pada brosur terdapat tujuh tahapan pengunaan dari alat tersebut. Meskipun memiliki tahap penggunaan lebih sedikit, tujuh tahap tersebut telah mencakup delapan tahap milik Osman $\operatorname{dkk}(2012)^{(10)}$ dan memberikan tahapan penggunaan tambahan yaitu pada tahap ketujuh yang merupakan poin penggunaan terakhir pada brosur. Tahap kesembilan milik Osman, adalah tahap yang tidak dijelaskan pada brosur MDI. Tujuh tahap penggunaan MDI menurut brosur obat MDI tersebut membatasi penjelasan penggunaan sampai tahap menahan nafas, sedangkan Osman $\operatorname{dkk}(2012)^{(10)}$ menambahkan tahapan lanjut yaitu untuk menghembuskan nafas secara perlahan-lahan setelah pasien menahan dosis obat agar terdeposit maksimal di paru-paru. Osman tidak menjelaskan mengenai aturan penggunaan dosis kedua, yang pada leaflet dijelaskan pada tahap terakhir (tahap ketujuh), untuk menunggu 30 detik sebelum menggunakan dosis kedua dengan mengulang langkah kedua sampai keenam (Tabel 9).Tahap ini menekankan pemberian jarak waktu untuk penggunaan dosis kedua, resiko yang didapatkan bila terjadi informasi error pada tahap ketujuh brosur adalah berkurangnya atau tidak adanya dosis obat yang dikeluarkan oleh inhaler pada saat pemakaian, karena metering chamber belum terisi kembali sepenuhnya $^{(13)}$.

Penelitian ini merupakan penelitian observasional kuantitatif dengan data informasi tambahan sebagai data kualitatif. Data kuantitatif digunakan untuk mencari generalisasi, dalam hal ini menghasilkan tingkat kemampuan apoteker. Proses kategori didasarkan pada hasil pengamatan dan penilaian yang rentan terjadi perbedaan persepsi antara peneliti satu dan peneliti lain maupun antar peneliti dan pengumpul data. Penelitian ini menggunakan dua pengumpul data, yaitu peneliti sebagai pengumpul data pertama dan seorang pengamat selain peneliti sebagai pengumpul data kedua. Peneliti dan pengamat dua masing-masing memberikan penilaian terhadap setiap kemampuan apoteker. Persepsi yang didapatkan dari dua orang pengumpul data akan diuji kesamaan persepsi untuk menghasilkan data penelitian yang akurat. Data yang diuji kesamaan persepsi adalah data ordinal, dalam penelitian ini adalah tingkat kemampuan apoteker berdasarkan tahap critical step yang terdiri dari 5 kategori dan dihitung dengan statistik kappa. 
Tabel 9. Tahap Penggunaan MDI Menurut Pustaka Osman dan Salah satu Brosur Obat MDI yang Mengandung Kortikosteroid

\begin{tabular}{ll}
\hline No. & Tahapan pengguaan alat MDI ${ }^{(10)}$ \\
\hline $1 *^{*}$ & Buka tutup inhaler \\
& \\
$2 . *$ & Kocok inhaler beberapa kali. \\
3. & Berdiri dan pada posisi kepala \\
& tegak, pastikan memegang inhaler \\
& dengan bagian mouthpiece (mulut \\
& inhaler) berada pada posisi bagian \\
& bawah.
\end{tabular}

4. Hembuskan nafas secara perlahan sampai tidak ada sisa udara yang dapat dihembuskan.

5. Posisikan mulut inhaler mengarah ke rongga mulut yang terbuka. Dan aliran udara tidak terganggu, dengan jalan lidah tidak menutupi bagian mulut inhaler.

6.* Tekan canister (ujung bagian atas inhaler) untuk mengeluarkan dosis, dan pada waktu bersamaan mulailah menarik nafas dalam secara perlahan (koordinasi)

7. Lanjutkan untuk bernapas perlahanlahan selama 4-5 detik

No. Tahapan penggunaan MDI (brosur)

1. Buka penutup mulut inhaler dan lakukan cek kebersihan pada bagian sisi dalam dan luar bagian mulut inhaler.

2. Kocok inhaler beberapa kali.

3. Tahan inhaler dalam posisi tegak, antara jari dan ibu jari, dengan ibu jari berada pada posisi dasar, yaitu dibawah mulut inhaler.

4. Buanglah nafas keluar senyaman mungkin melalui mulut, kemudian letakkan mulut inhaler di dalam mulut di antara gigi dan posisikan bibir dalam kondisi menutup. Inhaler tidak dikondisikan dalam keadaan tergigit.

5. Saat akan memulai menarik nafas melalui mulut, tekan ke bawah bagian atas inhaler untuk mengeluarkan salmeterol dan fluticasone propionate, tetap melanjutkan menarik nafas (dalam)

6. Tahan nafas, dan pindahkan inhaler dari mulut, jauhkan jari dari bagian atas inhaler (mencegah pengeluaran dosis), lanjutkan menahan nafas sepanjang nyaman.

7. Untuk memulai dosis kedua, tunggu 30 detik sebelum mengulang langkah ke 2-6.

8. Tahan napas selama 10 detik

9. Hembuskan nafas secara perlahan lahan

Berdasarkan hasil penelitian yang diperoleh, ditemukan beberapa keterbatasan penelitian sebagai berikut: (1) Besar sampel penelitian dari apoteker yang relatif kecil menyebabkan hasil penelitian belum menggambarkan kemampuan menjelaskan dari apoteker sebagai tenaga kefarmasian yang bertanggung jawab dalam pemberian konseling di apotek; (2) Penelitian ini tidak dapat menggambarkan kemampuan pasien asma di kabupaten Tuban dalam menggunakan MDI, namun hanya menggambarkan kemampuan tenaga kefarmasian.

\section{SIMPULAN}

Berdasarkan penelitian yang dilakukan dapat diambil kesimpulan bahwa apoteker di kabupaten Tuban, memiliki tingkat kemampuan kurang dengan persentase tertinggi, kemudian diikuti dengan teknik adekuat, dan teknik optimal 
dalam memberikan kelengkapan informasi penggunaan MDI untuk pasien asma. Apoteker mengetahui cara penggunaan MDI dan tidak ada apoteker yang tidak mengenali atau tidak familiar terhadap MDI sebagai terapi asma. Apoteker di kabupaten Tuban memiliki kecenderungan untuk hanya menginformasikan empat tahap dari sembilan tahap penggunaan MDI dari Osman dkk (2012), yaitu pada tahap ke-1, ke-3, ke-5, dan ke-6 penggunaan MDI.

\section{DAFTAR PUSTAKA}

1. Odili VU, Okoribe CO, 2010, Assessment of Pharmacists' Knowledge on Correct Inhaler Technique : Research Journal of Pharmaceutical, Biological and Chemical Sciences.

2. Direktorat Bina Farmasi Komunitas dan Klinik Didjen Bina Kefarmasian dan Alat Kesehatan Departemen kesehatan RI Tahun 2007, Pharmaceutical Care Untuk Penyakit Asma, 7-18

3. Oemiati R, Sihombing M, Qomariah, 2010, Faktor - Faktor yang Berhubungan dengan Penyakit Asma di Indonesia : Corelation Factor of Asthma Diseases in Indonesia.

4. Global Initiative for Asthma, 2015, Global Strategy For Ashtma Management and Prevention.

5. Baddar SA, Alrawas OA, Alriyani KA, dkk, 2001,Metered Dose Inhaler Technique among Healthcare Providers
Practising in Oman : SQU Journal for Scientific Research. I : 39 - 43

6. Terzano C, 2001, Pressurized Metered Dose Inhaler and Add on Devices, Pulmonary Pharmacology \& Therapeutics. 14 :351-366.

7. National Asthma Council Australia, 2008, Asthma Management Handbook

8. Onda M, Sakurai H, Hayase Y, dkk, 2009, Effect of Patient - Pharmacist Communication on the Treatment of Asthma: The Pharmaceutical Society of Japan. $129: 427-433$

9. Keputusan Menteri Kesehatan Republik Indonesia Nomor 1027 Tahun 2004 tentang Standar Pelayanan Kefarmasian di Apotek, 3-7

10. Osman A, Hassan A, Ibrahim M, dkk, 2012 , Are Sudanese Community Pharmacists Capable to Prescribe and Demonstration Asthma Inhaler Device to patient? A mystery study. Pharmacy Practise 2012 Apr-Jun ; 10-2 ; 110-11

11. Nadi E, Zeraati F, 2005, Evaluation of the Metered Dose Inhaler Technique among Healthcare Providers : Department of Internal Medicine. 43 : 4

12. Lazarus A, 2009, Psychiatric Services Improving Psychiatric Sevice Through Mystery Shopping, vol 60 No 7 : 972973

13. Beaucage D \& Nesbitt S, 2002 Chronic Obstructive Pulmonary Disease, McGraw-Hill Australia, Australia, 91-94 